\title{
NURSING CARE IN A HEMATOPOIETIC STEM CELLS TRANSPLANTATION UNIT ${ }^{1}$
}

\author{
Kaoana Lima², Elizabeth Bernardino ${ }^{3}$
}

\begin{abstract}
${ }^{1}$ Manuscript based on thesis - Functions and contributions of nurses in hematopoietic stem cell transplantation, presented to the Graduate Nursing Program at Universidade Federal do Paraná (UFPR), in 2011.

${ }^{2}$ M.Sc. in Nursing. Nurse at Hospital de Clínicas da UFPR. Curitiba, Paraná, Brazil. E-mail: kao_lima@hotmail.com

${ }^{3}$ Ph.D. in Nursing. Adjunct Professor, Nursing Department at UFPR. Associate Professor at Université Laval. Québec, Canada. E-mail: elizabeth.bernardino@hotmail.com
\end{abstract}

\begin{abstract}
In hematopoietic stem cell transplantation units, nursing care is different from other services. The objective in this descriptive study with a qualitative approach was to identify the care activities of nurses at a transplantation unit, classified according to the framework of nurses' functions. The data were collected through systematic observation and treated through content analysis. Three functions were identified for nurses: clinical nurse, management nurse and visit nurse, the first having a wider range of care activities. The maintenance of life care is focused on patient and environmental hygiene; the general techniques involve basic techniques like instrument/drug handling and patient assessment; and the specialized care includes specific activities, such as bone marrow collection and infusion, central catheter care and care for blood transfusion and chemotherapy. It was concluded that the care is integral, specialized and based on knowledge gained through additional training and expertise.
\end{abstract}

DESCRIPTORS: Bone marrow transplantation. Hematopoietic stem cell transplantation. Nurse's role. Nursing care.

\section{O CUIDADO DE ENFERMAGEM EM UNIDADE DE TRANSPLANTE DE CÉLULAS-TRONCO HEMATOPOÉTICAS}

\begin{abstract}
RESUMO: Em unidade de transplante de células-tronco hematopoéticas o cuidado de enfermagem mostra-se diferenciado em relação a outros serviços. Estudo descritivo de abordagem qualitativa que objetivou identificar atividades de cuidado dos enfermeiros de uma unidade de transplante classificada segundo o referencial de funções do enfermeiro. A coleta de dados deu-se pela observação sistemática e o tratamento dos dados por meio da análise de conteúdo. Identificaram-se três cargos de enfermeiros: assistencial, gerencial e enfermeiro da visita, sendo o primeiro com maior diversidade de atividades de cuidado. Os cuidados de manutenção da vida direcionam-se para higiene do paciente e do ambiente; os técnicos gerais envolvem técnicas básicas como manipulação de instrumentos/medicações e avaliação dos pacientes; e os especializados abrangem atividades específicas, como coleta e infusão de medula óssea, cuidados com cateter central e com hemotransfusão e quimioterápicos. Concluiu-se que o cuidado é integral, especializado e fundamentado em conhecimentos adquiridos pela formação complementar e expertise.
\end{abstract}

DESCRITORES: Transplante de medula óssea. Transplante de células-tronco hematopoéticas. Papel do profissional de enfermagem. Cuidados de enfermagem.

\section{CUIDADOS DE ENFERMERÍA EN UNIDAD DE TRASPLANTE DE CÉLULAS MADRE HEMATOPOYÉTICAS}

\begin{abstract}
RESUMEN: En la unidad de trasplante de células madre hematopoyéticas cuidados de enfermería se presenta de manera diferente de otros servicios. Un enfoque descriptivo cualitativo tuvo como objetivo identificar las actividades de atención de enfermería de una unidad de trasplante clasificados de acuerdo con una referencia de funcións de la enfermera. La recolección de datos se realizó a través de la observación sistemática y el proceso de datos a través de análisis de contenido. Se identificaron tres posiciones para las enfermeras: clínica, de la gestión y de la visita, siendo la primera una gama más amplia de actividades de atención. El cuidado del mantenimiento de la vida se centran en la atención al paciente y el medio ambiente; le cuidado general técnico incluyen técnicas básicas como el manejo de instrumentos/medicamentos y la evaluación de los pacientes; y los especiales cubren determinadas actividades, como la recolección y la infusión de médula ósea, el cuidado del catéter central y de la transfusión de sangre y de la quimioterapia. Se concluyó que la atención sea integral, especializado y basado en los conocimientos adquiridos por formación complementaria y especialización. DESCRIPTORES: Trasplante de médula ósea. Trasplante de células madre hematopoyéticas. Rol de la enfermera. Atención de enfermería.
\end{abstract}




\section{INTRODUCTION}

Hematopoietic stem cell transplantation (HSCT) is a treatment modality for hematological, oncological, hereditary and immunological diseases, which consists in the intravenous infusion of hematopoietic stem cells to reestablish the patients' medullary and immune function. The hematopoietic cells used for transplantation are obtained from bone marrow, peripheral blood or umbilical cord and placenta blood, coming from a donor or the patient. ${ }^{1}$ In many cases, this form of treatment shows to be the only chance of cure for onco-hematological patients, with very satisfactory results.

The HSCT process is very aggressive and involves the use of chemotherapeutic drugs, radiotherapy sessions, blood transfusions and other treatments, entailing countless risks for the patients' health. Thus, in the course of the process, the patient needs specific care to overcome the organic problems deriving from this treatment.

The established hospitalization time for the transplantation is about one month. The actual recovery of the bone marrow, however, happens slowly in the course of six to twelve months, when the patient still needs continuous health care and is at risk of development complications, often needing new hospitalizations. Consequently, the emotional suffering the transplantation process causes is very significant. ${ }^{2}$

The nurse-patient relationship is the most extensive and tight among all the professionals involved in HSCT. Due to the critical and unstable nature of the transplanted patient, nurses working in this area should possess specific knowledge for the elaboration of a detailed therapeutic plan, as they act decisively in all treatment phases. ${ }^{3}$

The theoretical framework of nurses' functions, used in this study as a theoretical-methodological reference framework, ${ }^{4-5}$ indicates that taking care is the nurses' basic function, comprising care to maintain life and general and specialized technical care.

In view of the particularity of nursing care in HSCT, the question that guided this study was: what are the care activities of nurses who work at an HSCT unit? The research objective was to identify the care activities of nurses at a transplantation unit, classified according to the Canadian theoretical reference framework of nurses' functions. ${ }^{4-5}$

A study about the scientific production on HSCT nursing ${ }^{6}$ indicated that there are a small number of publications about the nursing work process in this area, distinguished from other services. Thus, this study intends to contribute to the scientific community by describing the dynamics of nursing care at a transplantation unit, as this is the main function of nurses at this service.

\section{METHOD}

Study characterized as descriptive and qualitative, undertaken in May 2011 at an HSCT sector of a hospital located in the State of São Paulo. The activities of the nurses working at this service were identified through non-participant systematic observation, involving 12 out of 21 nurses at the service, who were working during the day shift at the time of the data collection. In total, 77 hours of observation were accomplished.

The nurses were accompanied throughout the work shift and their activities were identified and registered on observation forms. Adopting the content analysis ${ }^{7}$ technique to analyze the data, the observed activities were categorized according to the 'boxing' procedure, ${ }^{7}$ in which the categories are established in advance and the data are grouped as they are found. Thus, the predefined categories were the nurses' functions, defined according to the theoretical reference framework used ${ }^{4-5}-$ caring, educating, cooperating, coordinating and supervising - and the observed activities were grouped inside each function, according to the definition of each. For the categorization, figures were elaborated with the description of the activities belonging to each category.

Approval for the research project was obtained from the Research Ethics Commission of the institution involved and registered under opinion CEPFHAC $10 / 11$ on February $11^{\text {th }} 2011$. The subjects signed the Free and Informed Consent Term.

The complete results related to the five functions described in the Canadian theoretical reference framework by Clémence Dallaire. ${ }^{4-5}$ In this manuscript, however, the care function is discussed, due to the range of activities related to this function.

\section{RESULTS AND DISCUSSION}

At the HSCT service where the study was carried out, the nursing team is subdivided in three functions: management nurse (a professional responsible for managing the service), clinical nurse (twenty professionals responsible for direct 
and integral care delivery to the patients) and visit nurse (responsible for bureaucratic supervision and coordination activities). The latter are the same professionals working in care delivery, but are scaled weekly to work in this other function.

The systematic observation involved all of the nurses in the different activities relevant to their functions. The activities identified were classified based on the definition of each function. The life maintenance care is the basic care the subject normally performs when in a favorable health condition. When this condition has altered, however, nursing becomes responsible. General technical care refers to the basic nursing procedures, such as the physical examination, dressing change and medication administration, while the specialized techniques are characterized by a high complexity level and are specific to the activity area. Based on these definitions, figures 1, 2 and 3 present the activities the nurses perform, grouped in the category of the care function.

Figure 1 - Activities of clinical nurse in the care function. Brazil, 2011

\begin{tabular}{|c|c|}
\hline \multicolumn{2}{|r|}{ Life maintenance care } \\
\hline \multirow{5}{*}{ Self-care activities } & Forwarding of patient for bathing, supply of pajama and clean towels. \\
\hline & Help for dependent patient to get dressed. \\
\hline & Supply of body hydration oil for patients with GVHD* and help to apply it. \\
\hline & Supply of mouthwash for oral hygiene. \\
\hline & Preparation of bed bath for patients with diarrhea complications. \\
\hline \multirow[b]{2}{*}{ Environmental care } & Change of patients' bedpans and urinals. \\
\hline & $\begin{array}{l}\text { Change of bed linen and cleaning of bed, washing and organization of nursing station, } \\
\text { disinfection of surfaces. }\end{array}$ \\
\hline \multicolumn{2}{|r|}{ General technical care } \\
\hline \multirow[b]{2}{*}{ Patient protection } & Storage of personal belongings in locker; dressing with uniform of the institution. \\
\hline & $\begin{array}{l}\text { Handwashing and disinfection before and after: entering the unit, preparing and admin- } \\
\text { istering medication, having contact with the patient, handling eliminations. }\end{array}$ \\
\hline \multirow{4}{*}{$\begin{array}{l}\text { Verification and monitor- } \\
\text { ing of patient data }\end{array}$} & Verification of patient and related donor's vital signs. \\
\hline & $\begin{array}{l}\text { Verification of oxygen saturation levels, weight, abdominal circumference and capillary } \\
\text { glucose. }\end{array}$ \\
\hline & Hydric balance control. \\
\hline & Register of data to monitor the patient. \\
\hline \multirow{4}{*}{$\begin{array}{l}\text { Care for medication } \\
\text { therapy }\end{array}$} & Infusion control of medication installed by previous shift. \\
\hline & $\begin{array}{l}\text { Administration of intravenous, oral and inhalation medication, verification of adminis- } \\
\text { tered drugs in medical prescription. }\end{array}$ \\
\hline & Puncture and maintenance of peripheral venous access. \\
\hline & Identification and storage of medication leftovers. \\
\hline \multirow{2}{*}{$\begin{array}{l}\text { Response to patient } \\
\text { requests }\end{array}$} & Response to calls by patients or companions using bells. \\
\hline & Receipt of patient complaints. \\
\hline \multirow{5}{*}{ Care related to procedures } & $\begin{array}{l}\text { Forwarding and reception of patients from operating room for installation or removal of } \\
\text { Hickman catheter. }\end{array}$ \\
\hline & Patient preparation for tests. \\
\hline & Collection of blood tests. \\
\hline & Forwarding of bone marrow blood samples for tests. \\
\hline & Forwarding of bone marrow bag to apheresis unit after collection at operating room. \\
\hline \multirow{2}{*}{$\begin{array}{l}\text { Execution of Nursing } \\
\text { Care Systemization }\end{array}$} & $\begin{array}{l}\text { Interview, physical examination, nursing diagnoses, nursing prescription, execution of } \\
\text { nursing prescription and verification of care, nursing notes, nursing evolution. }\end{array}$ \\
\hline & Register of $\mathrm{NCS}^{\dagger}$ steps in standard instruments. \\
\hline
\end{tabular}




\begin{tabular}{|c|c|}
\hline \multirow{5}{*}{$\begin{array}{l}\text { Disposal and storage of } \\
\text { waste and materials }\end{array}$} & Disposal of waste in appropriate containers. \\
\hline & Storage of materials and clothing in washer after use. \\
\hline & Cleaning of medication trays after use. \\
\hline & Exchange of overdue alcohol flasks and identification of flasks. \\
\hline & $\begin{array}{l}\text { Operating room: disposal of waste, materials and clothing in appropriate places; clean- } \\
\text { ing of used materials with enzymatic product; forwarding of materials for washing and } \\
\text { material center. }\end{array}$ \\
\hline \multicolumn{2}{|r|}{ Specialized technical care } \\
\hline \multirow{4}{*}{ Care for Hickman catheter } & Dressing and fixation change. \\
\hline & Vessel maintenance and heparinization. \\
\hline & Measuring of catheter length. \\
\hline & Infection prevention activities. \\
\hline \multirow{5}{*}{$\begin{array}{l}\text { Care for intravenous } \\
\text { therapy }\end{array}$} & Preparation of intravenous substances in the laminar flow hood. \\
\hline & Blood transfusion care. \\
\hline & Care for parenteral nutrition infusion. \\
\hline & Care for chemotherapy infusion. \\
\hline & Care for thymoglobuline infusion. \\
\hline \multirow{3}{*}{ Procedure-related care } & Doing an electrocardiogram. \\
\hline & Bone marrow blood collection at operating room. \\
\hline & Hematopoietic stem cell infusion. \\
\hline Platelet activities & Platelet control and distribution activities. \\
\hline
\end{tabular}

* GVHD - graft-versus-host disease; †NCS - nursing care systemization.

\section{Figure 2 - Activities of visit nurse in care function. Brazil, 2011}

\begin{tabular}{|l|l|}
\hline \multicolumn{2}{|c|}{ General technical care } \\
\hline Patient protection & $\begin{array}{l}\text { Storage of personal belongings in locker; clothing using institutional uniform, hand wash- } \\
\text { ing before entering the unit. }\end{array}$ \\
\hline \multirow{5}{*}{ Patient forwarding } & $\begin{array}{l}\text { Patient reception for hospitalization at the unit; patient forwarding to nursing ward and } \\
\text { to clinical nursing. }\end{array}$ \\
\cline { 2 - 3 } $\begin{array}{l}\text { Patient forwarding to operating room attendant for withdrawal and installation of Hick- } \\
\text { man catheter. }\end{array}$ \\
\hline registers & $\begin{array}{l}\text { Double-checking of blood products together with clinical nursing team and attachment of } \\
\text { blood product bag label in patient file. }\end{array}$ \\
\cline { 2 - 2 } & \begin{tabular}{l} 
Double-checking of chemotherapeutic drugs with clinical nursing team. \\
\cline { 2 - 3 } Checking in patient file if pre-transplantation tests were done.
\end{tabular} \\
\cline { 2 - 2 } & $\begin{array}{l}\text { Transmission of medical platelet prescription to platelet nurse for internal and external } \\
\text { release to the sector. }\end{array}$ \\
\hline
\end{tabular}

Figure 3 - Activities of management nurse in care function. Brazil, 2011

\begin{tabular}{|l|l|}
\hline \multicolumn{1}{|c|}{ General technical care } \\
\hline Patient protection & $\begin{array}{l}\text { Storage of personal belongings in locker; clothing using institutional uniform, hand washing } \\
\text { before entering the unit. }\end{array}$ \\
\hline \multicolumn{1}{|c|}{ Specialized technical care } \\
\hline $\begin{array}{l}\text { Reception of bags with frozen umbilical cord blood for transplantation, together with physician and visit nurse, and } \\
\text { bag storage care. }\end{array}$ \\
\hline Request for mesenchymal cells to other institution for GVHD* treatment. \\
\hline
\end{tabular}

* GVHD -graft-versus-host disease. 
According to the theoretical framework of nurses' functions, care is the professionals' main function. The main care class, life maintenance, is developed under the particular conditions of a disease or weakness that justifies the nursing intervention..$^{4-5}$ In this category, activities are grouped which the clinical nurse developed for self-care and environmental care purposes (Figure 1).

The nursing interventions used in this function are countless. Among them, the reference framework indicates hygiene care, which is a frequent task among the nurses in this study. ${ }^{4-5}$ As a result of concerns with patient contamination, the nurses perform a range of care related to the cleaning of all utensils the patient will have contact with.

The hygiene care for hospitalized patients require considerable knowledge of the health and disease phenomena, of the potential modifications the health problems induce, such as fragility and vulnerability, and knowledge about the cure process. ${ }^{4}$ In this transplantation service, it is observed that the nurses have incorporated the knowledge about the patients' particularities and their vulnerability as a result of the treatment and apply it in care.

The patients' immunosuppression does not allow them to accomplish some hygiene care, particularly environmental hygiene. On the other hand, the patients themselves perform body and oral hygiene activities, as most of them have neither neurological nor physical mobility impairments, but under nursing supervision due to the particularities of this care. This intervention permits an approximation with the reference framework, which indicates the nurse as the evaluator of self-care abilities who, based on these skills, adapts the care to favor the patients' execution, thus aiming to restore the self-care ability. ${ }^{4}$

The life maintenance care observed are as important as other more specialized care, as it is fundamental for the patient's recovery and the prevention of complications. The HSCT contexts demands distinguished nursing care, highlighting infection prophylaxis measures. ${ }^{8}$ The storage of personal belongings outside the unit, dressing the institutional uniform and hand washing, activities classified in the general technical care category, are included in this discussion because their objective is to protect the patient against micro-organisms coming from the external environment and to avoid cross-infections. Similarly, the nurses need specific knowledge on infection control and pro- tective isolation.

The technical nursing care is defined as the necessary restoration care in view of the disease, delivered in combination with the life maintenance care $^{4-5}$ At the place of study, the technical care involves monitoring, treatment, evaluation and response to the patient's needs during the transplantation process.

The technical care is mostly performed by the clinical nurses, but activities in this category were also observed among visit and management nurses. Among the general care (Figure 1), hand washing stands out, an activity the team values and the three nursing categories frequently develop during the work shift. Hand washing is the most effective infection control measure and a practice the nurses working in HSCT acknowledge as fundamental in care delivery to immunocompromised patients, ${ }^{8}$ a fact that was also observed in the study. This practice also follows the standards of the National Health Surveillance Agency (ANVISA) with regard to hand washing as an infection prevention measure. ${ }^{9}$

The verification of the vital data and other values that permit monitoring the patient's evolution during the treatment, as well as the hydric balance control, were activities observed in the clinical nurses and classified as general technical care, because this is an extremely specialized service with other more complex activities. In addition, care activities for medication therapy, response to patient requests and procedurerelated care were observed, mostly delivered by the clinical nurses, but also accomplished in the other categories' activities.

The Nursing Care Systemization (NCS) is found in all phases, particularly this professional's specific activities, guiding and supervising the secondary-level professionals in their activities and also registering all information obtained in the nursing process, an activity also recommended by COFEN. ${ }^{10}$

The systemization of the nursing care observed among the study subjects involves competences established in COFEN Resolution $200 / 1997,{ }^{11}$ such as the registering of information and statistical data related to nursing care for transplanted patients and the elaboration of the nursing prescription for patients in HSCT.

In the HSCT process, it is fundamental for the adopted care method to be directed at the delivery of care by nurses and other nursing members through planned, developed or delegated actions 
among the team members. ${ }^{12}$ This idea supports the determinations of COFEN in Resolution 358/2009 that the nursing care systemization organizes professional work with regard to the method, staff and instruments, permitting the operation of the nursing process. Nurses in leadership positions in the execution and evaluation of the nursing process are exclusively responsible for nursing diagnoses and for the prescription of interventions. ${ }^{10}$

Another important activities in the general technical care function is the disposal and storage of waste and materials, environmental organization activities that are part of patient care. Nevertheless, they also cooperate with the service, as the institution executes risk management and waste separation. Hence, the nurse cooperates by performing these activities.

As regards the visit nurses, they are not responsible for direct patient care. Their activities are more related to coordination and supervision. Some general technical care, however, was observed when the nurses act together with the clinical team (Figure 2), such as patient forwarding and care for documentation and registering. The latter is accomplished through the verification of blood products and chemotherapeutic drugs together with the clinical team, enhancing the safety in the infusion of these solutions through double-checking. It was observed that this is not an exclusive activity of the visit nurses, but that they work together with the clinical team to complement this care activity.

During general care, the nurses observe, listen and communicate their impression so as to put order in the situation momentarily, temporarily or definitively. This care is part of all nurses' basic education, while specialized care is reserved to one group, requiring additional education. ${ }^{4-5}$

In the context of HSCT, the nurses deliver care to patients with severe health problems and are apt to attend to specific complications of transplantation and to deliver specialized care involving catheter maintenance, care for mucositis, skin, medication infusion and isolation methods, ${ }^{13}$ activities that were observed in the research.

The patients' complications mainly vary according to the transplantation type and the conditioning regimen they were submitted to, ${ }^{14}$ important aspects the nurse needs to take into account in symptom management. To give an example, patients submitted to allogeneic transplantation on myeloablative regimens present more severe complications than patients submitted to autologous transplantation. ${ }^{14}$

The specialized technical care activities, distributed in this category, required knowledge and specific skills from the nurses for the HSCT area, according to the functional reference framework in which the author describes them as care that demands instrument handing, knowledge of technologies and use of particular protocols from the nurses in order to intervene in more complex situations effectively..$^{4-5}$ In this service, the nurses exclusively perform many of the specialized activities, while their execution by the technical nursing team is not permitted.

The specialized technical care is predominantly executed by the clinical nurses (Figure 1). The first subcategory found in this function relates to the care for Hickman catheters. That is a central venous access device, frequently used in the transplantation service due to the need to infuse a large number of solutions to the patient during treatment, such as hydration serum, antibiotics, chemotherapeutic drugs, blood transfusions and the actual infusion of hematopoietic stem cells, so that percutaneous puncture is not needed. In addition, it is also used during blood collection for tests. ${ }^{15}$ As an indwelling device, ${ }^{16}$ the patient uses the catheter while in hospital and afterwards during outpatient monitoring.

The Hickman catheter is installed at an operating room and the nursing team at the hospitalization unit is responsible for its use and maintenance. It was observed that, each day, the dressing of the catheter insertion ostium is changed, a procedure developed with the use of an aseptic technique after the patient's bath. During this activity, the nurse has the opportunity to assess the conditions of the catheter and the underlying tissue, such as the fixation points, signs of skin infection or irritation due to the catheter fixation and traction.

Although widely used, the central catheter exposes the patient to complications, such as bloodstream and other infections. Therefore, care for its maintenance is fundamental, such as cleaning, inspection and palpation of the insertion site and exit ostium, application of a sterile occlusive dressing, disinfection and control of the expiry date of connections, as well as strict control of the solutions infused, ${ }^{17}$ all of which are nurses' activities.

The care related to the intravenous therapy was also classified as specialized techniques. This care starts during the preparation of these substances in a laminar flow hood, equipment with an 
air filtering system to control for microorganisms in medication preparation and in the protection against their toxic effects. ${ }^{16}$

Part of the activities related to the medication therapy was classified as general technical care and part as specialized. Medication administration was classified as general technical care because all nurses perform this practice and learn it since their basic education. The preparation of these drugs in the laminar flow hood, as well as the intravenous therapy of special solutions, such as blood products and chemotherapeutic drugs, demands specific knowledge from the professionals, as well as the use of technologies and service protocols. In addition, to execute these specialized activities, the nurses receive initial training in the service.

Among the procedures categorized as specialized technical care, bone marrow blood collection at the operating room and the infusion of hematopoietic stem cells are highlighted. These are exclusive activities of nurses at this service. Their execution by nursing technicians is not permitted. These activities follow COFEN Resolution $200 / 1997,{ }^{11}$ which establish the competency of HSCT nurses as the execution of specific technical procedures related to the aspiration and infusion of hematopoietic stem cells.

Bone marrow blood is collected at the operating room and involves a series of procedures, such as preparing the tables with sterile material for the collection, asepsis of the puncture site, storage of the bone marrow blood in a specific container after being collected by the physician and filtering and storing in a special bone marrow blood bag.

After the collection, the nurse returns to the transplantation unit to start the infusion of hematopoietic stem cells. Besides the marrow blood, the sector transplants peripheral and umbilical cord and placenta blood cells. Throughout the procedure, the nurse monitors the patient, assesses his/her general condition, periodically controls the vital signs and observes possible secondary reactions.

The professionals and patients inside the service highly value the hematopoietic stem cell collection and infusion activities. Both are the exclusive responsibility of the clinical nurses and these activities come with all expectations related to the treatment.

The final subcategory of specialized technical care refers to the platelet activities, performed by the clinical nurse. This transplantation unit stores all available platelets for use by the institution and the nurses are responsible for their control and distribution. Each week, one clinical nurse takes charge of these activities, which is also an exclusive activity for these professionals.

The platelet control involves activities that come with great responsibility, as platelet transfusion entails risks for the patient, requiring strict control before the transfusion. It is supposed that the institution delegates this activity to the nurses as they have knowledge about hemotherapy, about the organization and control of the inputs needed for care, besides the fact that there is a sufficient number of professionals for this activity, who can organize themselves between these and care activities.

A similar study undertaken at an Intensive Care Unit (ICU), also based on the reference framework of nurses' functions, ${ }^{18}$ already evidenced the predominance of specialized technical care by nurses. This fact demonstrates that the nurses have the knowledge and skills needed to apply this care, which cannot be delegated to the secondary-level nursing professionals. In the same study, ${ }^{18}$ it was also evidenced that the service has an appropriate rate of nurses/bed, which favors the effective performance of the care function, reduces possible errors and enhances the quality of the care delivered.

Like the visit nurse, the management nurse does not assume clinical activities. Some specialized technical care activities were observed though (Figure 3). One of them is the reception of hematopoietic stem cell bags of umbilical cord and placenta blood for transplantation, coming from other institutions. This activity involves responsibilities as the patient who will receive these cells depends on them for treatment, which is why it was classified as a specialized care activity. Similarly, the management nurse requests mesenchymal cells to other institutions. The use of mesenchymal cells has recently occurred for the treatment of graftagainst-host diseases.

When comparing the range of care activities delivered by the three nurse's functions, it was verified that clinical nurses have a wider range of activities at this service, which is expected, as they assume direct patient care.

Drawing a parallel with another similar study undertaken in the ICU context, ${ }^{18}$ it is observed that the nurses perform a wide range of coordination and supervision than care activities at such services. In HSCT, on the other hand, the care activities are predominant. This fact is due 
to the different forms of nursing work organization in these two environments. At the ICU, the number of nurses is small and their activities are more focused on care management than on the application of direct care. In HSCT, then, the number of nurses is large, permitting the comprehensive performance of care activities.

Hematopoietic stem cell transplantation was clearly established as an important treatment modality that is considerably expanding and evolving, with an increasingly small incidence rate of complications after the procedure. ${ }^{19}$ This is due to the different professionals' efforts, who develop research and work in the care process for transplanted patients, where nursing plays a significant role.

The nurses' contribution to successful transplantations in general is undeniable. Care in this area has gained increasing complexity, demanding high-quality care for patients and family members, in which nurses play a fundamental role as health team members. ${ }^{20}$

\section{FINAL CONSIDERATIONS}

As verified, at the HSCT unit, the nurses perform all kinds of care, efficiently intervening in the most simple as well as highly complex activities that need long periods of practice and training. Therefore, it is considered that the care is not parceled, that is, care delivery to transplanted patients is integral, with nurses attending to all of their health needs. The amount of specialized care and very specific activities is highlighted at the service. The knowledge for their execution is not gained during basic education, but through training and qualification, until reaching the level of expertise and the ability to assume the required responsibilities.

The decision was made to use a Canadian and up-to-date theoretical reference framework on nurses' functions, with a view to gaining a new perspective on these professionals' work in the context of HSCT. This framework demonstrated its relevance to support the research and achieve the proposed objectives. In view of the range of care activities executed in their daily work, the study provided an understanding of the nurses' care process at an HSCT service and contributed to apprehend the role of nurses working in this area. In addition, it was observed that the nurses comply with the determinations of the law on professional nursing practice and with the Federal
Nursing Council's regulations on nursing competences in HSCT.

The lack of quantitative data, including measures of the time the nurses spend on their activities, is considered a study limitation, as this could have contributed by defining on what functions the nurses spend more or less time in their daily work.

\section{REFERENCES}

1. Ortega ETT, Kojo TK, Lima DH, Veran MP, Neves MI. Compêndio de enfermagem em transplante de células-tronco hematopoiéticas: rotinas e procedimentos em cuidados essenciais e em complicações. Curitiba (PR): Editora Maio; 2004.

2. Costanzo ES, Juckett MB, Coe CL. Biobehavioral influences on recovery following hematopoietic stem cell transplantation. Brain Behav Immun. 2013; 30:68-74.

3. Anders JC, Soler VM, Brandão EM, Vendramini EC, Bertagnolli CLS, Giovani PG, et al. Aspectos de enfermagem, nutrição, fisioterapia e serviço social no transplante de medula óssea. Medicina. 2000 Out-Dez; 33:463-85.

4. Dallaire C. Les grandes fonctions de la pratique infirmière. cap. 2. In: Goulet $O$, Dallaire C. Soins infirmiers et société. Québec (CA): Gaëtan Morin Éditeur; 1999. p.33-51.

5. Dallaire C, Dallaire M. Le savoir infirmier dans les fonctions infirmières. cap. 11. In: Dallaire C, organizador. Le savoir infirmier: au couer de la discipline et de la profession. Montréal (CA): Gaëtan Morin Éditeur; 2008. p. 265-305.

6. Lima K, Bernardino E, Wolff LDG, Peres AM. Características da produção científica de enfermagem em transplante de células-tronco hematopoiéticas. Cogitare Enferm. 2012 Jul-Set; 17(3):568-73.

7. Bardin L. Análise de conteúdo. Lisboa (PT): Edições 70; 2010.

8. Zavadil ETC. Representações do enfermeiro sobre infecção em transplante de células-tronco hematopoiéticas [dissertação]. Curitiba (PR): Universidade Federal do Paraná Curitiba. Programa de Pós-Graduação em Enfermagem; 2010.

9. Brasil. Agência Nacional de Vigilância Sanitária (ANVISA) [página da Internet]. Segurança do paciente em serviços de saúde: higienização das mãos. Brasília (DF); 2009 [acesso 2011 Ago 22]. Disponível em: http:/ / bvsms.saude.gov.br/bvs/ publicacoes/seguranca_paciente_servicos_saude_ higienizacao_maos.pdf

10. Conselho Federal de Enfermagem. Resolução n. 358 , de 15 de outubro de 2009. dispõe sobre a sistematização da assistência de enfermagem e a implementação do processo de enfermagem em 
ambientes, públicos ou privados, em que ocorre o cuidado profissional de enfermagem, e dá outras providências. Rio de Janeiro (RJ): COFEN; 2009.

11. Conselho Federal de Enfermagem. Resolução n. 200, de 15 de abril de 1997: Dispõe sobre a atuação dos profissionais de enfermagem em hemoterapia e transplante de medula óssea. Rio de Janeiro (RJ): COFEN;1997.

12. Ortega ETT, Stelmatchuk AM, Cristoff C. Assistência de enfermagem em transplante de células-tronco hematopoéticas. cap. 37. In: Volterelli JC, Pasquini $\mathrm{R}$, Ortega ETT. Transplante de células-tronco hematopoéticas. São Paulo (SP): Editora Atheneu; 2009. p.1031-98.

13. Lacerda MR, Lima JBG, Barbosa R. Prática de enfermagem em transplante de células-tronco hematopoiéticas. Rev Eletr Enferm. [online]. 2007 [acesso 2011 ago 22] 9(1):242-50. Disponível em: http://www.fen.ufg.br/fen_revista/v9/n1/ v9n1a19.htm

14. Cohen MZ, Rozmus CL, Mendoza TR, Padhye NS, Neumann J, Gning I, et al. Symptoms and quality of life in diverse patients undergoing hematopoietic stem cell transplantation. J Pain Symptom Manage. 2012 Aug; 44(2):168-80.
15. Castanho LC, Silveira RCC, Braga FTMM, Canini SRMS, Reis PED, Voltarelli JC. Motivo de retirada do cateter de Hickman em pacientes submetidos ao transplante de células-tronco hematopoéticas. Acta Paul Enferm. 2011; 24(2):244-8.

16. Giovani AMM. Enfermagem, cálculo e administração de medicamentos. São Paulo (SP): Scrinium; 2006.

17. Pedrolo E, Danski MTR, Mingorance P, Lazzari LSM, Johann DA. Ensaio clínico controlado sobre o curativo de cateter venoso central. Acta Paul Enferm. 2011; 24(2):278-83.

18. Cenedési MG, Bernardino E, Lacerda MR, Dallaire C, Lima K. Funções desempenhadas pelo enfermeiro em unidade de terapia intensiva. Rev Rene. 2012; 13(1):94-102.

19. Devetten M, Armitage JO. Hematopoietic cell transplantation: progress and obstacles. Ann Oncol. 2007 Set; 18(9):1450-6.

20. Mendes KDS, Roza BA, Barbosa SFF, Schirmer J, Galvão CM. Transplante de órgãos e tecidos: responsabilidades do enfermeiro. Texto Contexto Enferm. 2012 Out-Dez; 21(4):945-53 [acesso 2013 Out 10]. Disponível em: http:/ / www.scielo.br/pdf/tce/ v21n4/27.pdf 